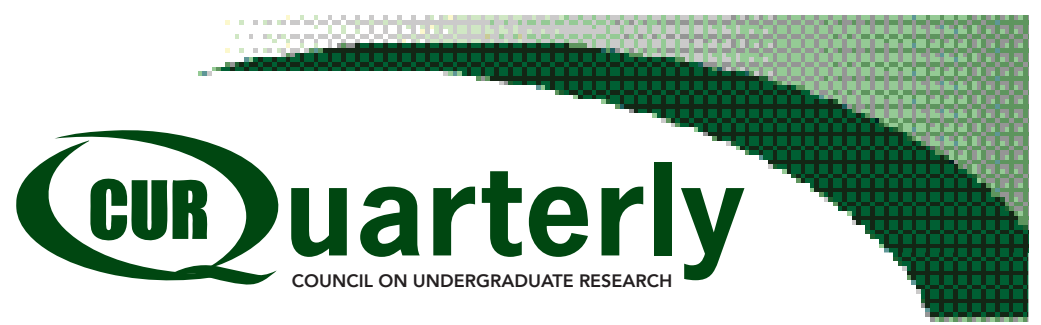

\title{
From the CURQ Issue Editor
}

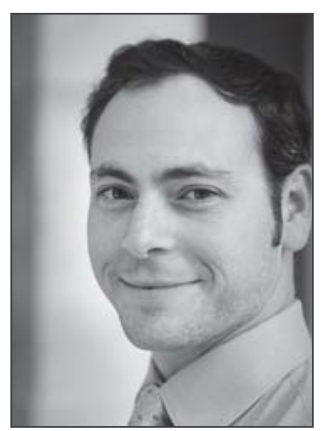

Solving the world's most complex and increasingly global challenges will require the integration of science and policy. As the next generation of researchers and policy leaders, undergraduates are playing a central role at this nexus. Science policy is typically defined as using scientific data to inform policy making (for example, collecting weather data to plan for climate change) or is looked at as a toolset for governing science (for example, used in debating funding levels for the National Science Foundation). I'm excited to say that current edition of the CUR Quarterly deals with both aspects of science policy and puts undergraduates front and center in this dynamic and essential field.

In fact, three of our pieces address various aspects of environmental policy, with each showcasing the vital role that undergraduates play in carrying out this research. In the print edition's "Undergraduate Research at the School for Field Studies Center for Marine Resource Studies in the Turks and Caicos Islands," Meghan Graham MacLean, Heidi Hertler, and Mark Seifert explore the contributions of undergraduate research for informing local-level policy at fisheries, a vital economic resource in the Islands. In fact, this research has uncovered that local consumption of conch has substantially exceeded the quota set out by governing authorities.

At the state level we have an article in CURQ on the Web, "Water Resource Policies in Montana: Interactive Roles for Undergraduates" by Susan Gilbertz. In this piece, Gilbertz lays out the role that undergraduate students from Montana State University played in enabling the formulation of a State Water Plan. In her piece, Gilbertz describes the students as an "indefatigable support team" who played a critical role in developing water policy for the state.

In another article in the print edition, "Interdisciplinary Community-Connected Capstone Courses: A Model for Engaging Undergraduate Students with Public Policy," Diane Munroe of Middlebury College outlines a practicum capstone course developed for undergraduates majoring in environmental studies. This course gives students insights into the real world challenges that come with policymaking and enables them to engage with legislators and state agencies, with the ultimate goal of helping to develop state policy.

In a similar vein, Patrick Killion and Ian Page examine a course in their print edition vignette, "The University of Maryland
First-Year Innovation and Research Experience (FIRE) Impacts Student Participation in Policy-Based Research." In the FIRE course, first-year undergraduates get an opportunity to engage in research and mentorship. Indeed, students get to select a focus area for their research projects, which are designed to have policy implications and impact.

And finally, in the print edition "Assessing NSF Grant Outcomes in the Social Sciences," by Kyle Kopko, Ashley Edwards, Erin Krause, and Vincent McGonigle, provides perspective on a Congressional debate sparked in 2013 when Senator Tom Coburn (R-OK) introduced an amendment to require additional oversight of NSF-funded grants in the social sciences. This move activated the social science advocacy community and other supporters who felt this was an overreach by Congress. The article examines the outcomes of NSFfunded social science grants from 2010 to 2012, which sheds light on the broader value of these research projects.

In summation, undergraduates played a vital role in each of the projects described in these articles, as researchers, policy advisors, and, in some cases, as citizen scientists who used their expertise to improve governance at the local, state, or national levels. Clearly, undergraduate research has a large and growing role to play in advancing science policy.

\section{Max G. Bronstein}

Founder, CEO, Journal of Science Policy and Governance Guest CURQ Issue Editor

doi: $10.18833 /$ curq/36/3/8

\section{CUR Calendar}

APRIL 2016

\begin{tabular}{c|l}
\hline $7-9$ & National Conference on Undergraduate \\
\hline $11-15$ & Undergraduate Research Week \\
\hline
\end{tabular}

JUNE 2016

$26-28$

CUR Biennial Conference, University of South Florida

Be sure to check www.cur.org for the most up-to-date news and the Event Calendar. 